This journal is the official publication of Bangladesh Society of Physiologists (BSP)

Web URL: www.banglajol.info/index.php/JBSP

Abstracted /indexed in Index Copernicus, Director of Open Access Journal, Index Medicus for South East Asia Region, Google Scholar, 12OR, infobse index, Open J gate, Cite factor, Scientific indexing services

pISSN-1983-1213; e-ISSN-2219-7508

Article

Article information:

Received on $15 / 8 / 2018$

Accepted on 13/11/2018

DOI: https://doi.org/10.3329/jbsp.v13i2.39480

Corresponding author:

Rahnuma Ahmad

Department of Physiology, Medical College

for Women and Hospital, Dhaka.

Email: rahnuma.ahmad@gmail.com

Cite this article:

Ahmad R, Akhter S. Effects of exposure to cement dust on hemoglobin concentration and total count of RBC in cement factory workers

J Bangladesh Soc Physiol 2018;13(2): 68-72

This article is open access licensed under CC BY NC SA which allows readers copy, distribute, display, and perform the work and make derivative works based on it only for noncommercial purposes.

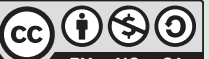

\section{Effects of exposure to cement dust on hemoglobin concentration and total count of RBC in cement factory workers}

\author{
Rahnuma Ahmad ${ }^{1}$, Qazi Shamima Akhter ${ }^{2}$ \\ 1. Department of Physiology, Medical College for Women and Hospital, \\ Dhaka. \\ 2. Department of Physiology, Dhaka Medical College, Dhaka.
}

\section{Abstract}

Background : Cement factory workers are exposed to cement dust during their daily work activities. Chronic exposure to cement dust may have adverse effect on the haemopoietic system and the workers would suffer from anemia that may lead to cardiovascular disease. Objective: To assess the effects of exposure to cement dust on hemoglobin concentration and total count of RBC in cement factory workers. Methods : This cross sectional study was conducted in the Department of Physiology, Dhaka Medical College, Dhaka from July 2017 to June 2018. After fulfilling the ethical consideration, 46 apparently healthy male cement factory workers, working in a cement factory for 2 years or more, with age ranging from 20 to 50 years were study group and 46 age, BMI and socioeconomic condition matched apparently healthy male subjects from different areas of Dhaka city were control group. Hemoglobin concentration and total count of RBC were estimated using automated haematology analyzer. For statistical analysis, Unpaired Student's ' $t$ ' test and Pearson's correlation coefficient test were performed. Results: In this study, hemoglobin concentration and total count of RBC were significantly $(p<0.05)$ lower in study group than those of control group. Hemoglobin concentration was negatively related with duration of cement dust exposure. Conclusions: This study concludes that the cement dust exposure had deleterious effect on hemoglobin concentration and total count of RBC and the duration of exposure to cement dust had an impact on hemoglobin concentration.

Key words: Cement dust, anemia. 
Introduction

A ccording to the "Glossary of Atmospheric Chemistry Terms", dust is defined as small, dry, solid particles projected into air by natural forces, such as wind, volcanic eruption, and by mechanical or processes that include smashing, fragmenting, drilling, dusting, packing. Dust particles are usually in size range from about 1 to $100 \mathrm{im}$ in diameter, and they settle slowly under the influence of gravity ${ }^{1}$.

Cement dust is a grey powder and has a diameter between the range of $0.05 i$ and $5.0 i^{2}$. It consists of $60-67 \%$ calcium oxide (lime), $17-25 \%$ silicon oxide, $3-5 \%$ aluminium oxide, with some amount of iron oxide, chromium, lead, potassium, sodium, sulphur, mercury, antimony, cadmium, zinc, manganese and magnesium oxide ${ }^{3}$.

Inhalation and swallowing are the two important routes by which cement dust chemicals enter the body to produce adverse effects ${ }^{4}$.Exposure to cement dust also occurs through eye and skin contact 5 .

In case of a single or short term exposure to cement dust, there is little to no hazard posed to human health. However, chronic exposure to cement dust can lead to deteriorating effects on skin, eye, respiratory and haematological system. Long term cement dust exposure causes irritation of exposed mucous membrane and leads to chronic respiratory diseases including pneumoconiosis, lung cancer $6,7,8$.

Cement industry is a rapidly growing sector in the world and also in Bangladesh. World cement production rose from 3.7 billion metric tons in 2012 to 5 billion metric tons in $2016^{9}$. There is emission of dust and particulate matter at the different steps of cement manufacture ${ }^{10}$. An estimated 29,000 deaths are caused by silica, asbestos and coal dust exposure worldwide per year ${ }^{11}$.

Several studies in different countries like Nigeria, India have suggested that cement dust exposure causes hematological changes that includes anemia. The hemoglobin cut off point for anemia in male is $13 \mathrm{~g} / \mathrm{dl}^{12}$. Anemia can lead to cardiovascular disease such as cardiac arrhythmia, ishchemic heart disease ${ }^{13}$.

Hematological parameters are sensitive index and may be useful as tools for indirect diagnosis and prognosis to assess the toxicity of cement dust ${ }^{5}$.Previous studies in different countries have shown changes in hemoglobin concentration and total count of RBC of the cement factory workers $2,5,14$. However, in Bangladesh, data is not adequate on this topic. The present study is designed to evaluate the effects of cement dust on hemoglobin concentration and total count of RBC of cement factory workers.

\section{Method}

This cross sectional study was conducted in the Department of Physiology, Dhaka Medical College, Dhaka from July 2017 to June 2018. Forty six apparently healthy male cement factory workers, working in a cement factory in Munshigonj for 2 years or more, with age ranging from 20 to 50 years were study group and forty six age, BMI and socioeconomic condition matched apparently healthy male subjects from different areas of Dhaka city were control group based on the inclusion and exclusion criteria. Subjects with history of respiratory disease, acute infection, cardiac disease, hematological disease, liver disease, renal disease, malignancies, hypertension; history of taking anticoagulant, chemotherapy, iron therapy and recent history of blood transfusion were excluded from the study. The study group was divided into two groups on the basis of duration of cement dust exposure, that is, subjects exposed to cement dust for 2-6 years and subjects exposed for 7-12 years.

After selection of the subjects informed written consent was taken from them. The research work was carried out after obtaining ethical clearance from Ethical Review Committee of Dhaka Medical College, Dhaka. All the information was recorded in a pre-designed data schedule. With aseptic precaution, $2 \mathrm{ml}$ of venous blood were collected from ante-cubital vein and taken in a tube with EDTA anticoagulant for estimation of hemoglobin concentration and total count of RBC. The collected blood sample was analyzed in the 
Department of Laboratory Medicine, Dhaka Medical College hospital, Dhaka using Horiba Pentra DX Nexus automated haematology analyzer. Statistical analysis was performed by using SPSS (Statistical Package for Social Sciences) Version 16. Data were presented as mean and standard deviation (mean $\pm \mathrm{SD}$ ). Unpaired Student's ' $t$ ' test was done to compare between the groups and correlation was analyzed by Pearson's correlation co-efficient (r) test. $p$ value of $<0.05$ was taken as level of significance.

\section{Result}

In this study no statistical differences were observed in age, BMI, socioeconomic condition, systolic and diastolic blood pressure between groups (Table I). Hemoglobin concentration and total count of RBC were significantly lower in the cement dust exposed subjects in comparison to the control group (Table II). Nineteen study subjects (41\%) exposed to cement dust had mean hemoglobin concentration less than $13.0 \mathrm{~g} / \mathrm{dL}$. Among them, significantly lower mean hemoglobin concentration was observed in subjects in the age range of 20-35 years who were exposed for 7-12 years. Twenty seven cement dust exposed subjects had mean hemoglobin concentration within normal range (e" $13.0 \mathrm{~g} / \mathrm{dL}$ ). Among them, significantly lower mean hemoglobin concentration was noted in subjects in the age range of 36-50 years who were exposed for 7-12 years (Table III). Hemoglobin concentration showed negative correlation with duration of cement dust exposure, which was statistically significant $(p<0.001)$ (Figure 1).
Table I : General characteristics of the subjects in both groups $(\mathrm{N}=92)$

\begin{tabular}{lcc}
\hline & $\begin{array}{c}\text { Cement factory } \\
\text { workers }(\mathrm{n}=46)\end{array}$ & $\begin{array}{c}\text { Control } \\
(\mathrm{n}=46)\end{array}$ \\
\hline Age $(\text { years })^{\mathrm{a}}$ & $33.17 \pm 8.27^{\mathrm{ns}}$ & $33.52 \pm 7.87$ \\
$\mathrm{BMI}\left(\mathrm{kg} / \mathrm{m}^{2}\right)^{\mathrm{a}}$ & $23.14 \pm 2.06^{\mathrm{ns}}$ & $23.71 \pm 2.61$
\end{tabular}

Socioeconomic condition

Low $\quad 46(100 \%) \quad 46(100 \%)$

Systolic BP (mmHg) $117.72 \pm 15.06113 .04 \pm 12.09$

Diastolic BP (mmHg) $\quad 71.74 \pm 9.51 \quad 70.87 \pm 9.11$

Data shown as Mean $\pm \mathrm{SE}$, Statistical analysis was done by Unpaired Student's 't' test,

Control=Healthy adult subjects not exposed to cement dust, $\mathrm{BMI}=$ Body mass index, $\mathrm{BP}=$ blood pressure.

Table II: $\mathrm{Hb} \%$ \& TC of RBC of the subjects in both groups $(\mathrm{N}=92)$

\begin{tabular}{lcc}
\hline Parameters & $\begin{array}{l}\text { Cement factory } \\
\text { workers }(\mathrm{n}=46)\end{array}$ & $\begin{array}{l}\text { Control } \\
(\mathrm{n}=46)\end{array}$ \\
\hline $\begin{array}{l}\text { Hb concentration } \\
(\mathrm{g} / \mathrm{dL})^{\mathrm{a}}\end{array}$ & $12.91 \pm 1.84^{* * *}$ & $14.40 \pm 1.23$ \\
$\mathrm{RBC}$ count & $4.79 \pm 0.84^{* *}$ & $5.18 \pm 0.48$ \\
$\left(\mathrm{x} 10^{6} / \mu \mathrm{l}\right)^{\mathrm{a}}$ & & \\
\hline
\end{tabular}

Data were shown as mean \pm SE .Statistical analysis was done by Unpaired Student's ' $\mathrm{t}$ ' test. $\mathrm{N}=$ total number of subjects. $\mathrm{Hb}=$ hemoglobin, $\mathrm{RBC}=$ red blood cell, (* Cement factory workers vs Control group) $* * *=p<0.001, * *=p<0.01 . \mathrm{n}=$ number of subjects in each group

Table III:Comparison of mean hemoglobin concentration with age and duration of cement dust exposure $(\mathrm{N}=46)$

\begin{tabular}{lcccc}
\hline Age (years) & \multicolumn{4}{c}{ Hb concentration in study group $(\mathrm{g} / \mathrm{dL})$} \\
\cline { 2 - 5 } & & \multicolumn{3}{c}{$\geq 13.0$} \\
& $2-6$ years $(\mathrm{n}=6)$ & $7-12$ years $(\mathrm{n}=13)$ & $2-6$ years $(\mathrm{n}=16)$ & $7-12$ years $(\mathrm{n}=11)$ \\
\hline $20-35(\mathrm{n}=29)$ & $12.00 \pm 0.50$ & $10.05 \pm 0.35^{* * *}$ & $14.86 \pm 0.63$ & $13.51 \pm 0.30^{\mathrm{ns}}$ \\
$36-50(\mathrm{n}=17)$ & - & $10.95 \pm 0.90$ & $15.00 \pm 0.50$ & $13.35 \pm 0.05^{\#}$ \\
\hline
\end{tabular}

Data were shown as mean \pm SE .Statistical analysis was done by Unpaired Student's ' $t$ ' test (a) for comparison between groups. Study group $=$ study subjects exposed to cement dust, $\mathrm{n}=$ total number of subjects in each group. $\mathrm{Hb}=$ hemoglobin, $* * *=p<0.001, \#=p<0.05$, ns= not significant . 


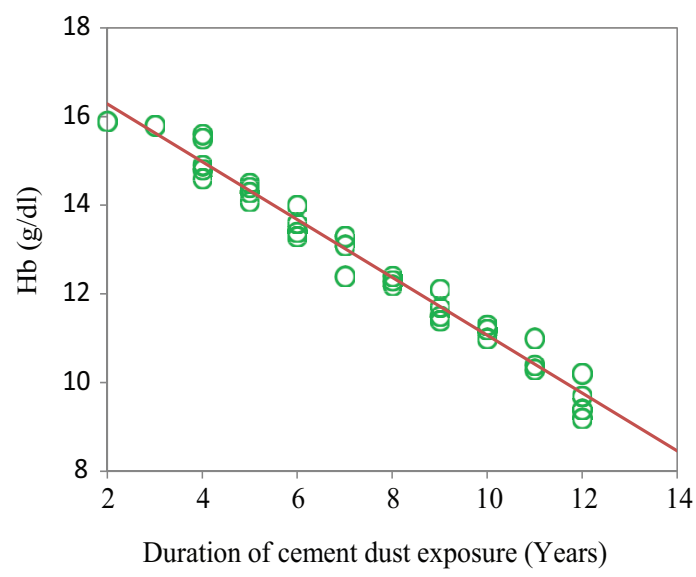

Figure 1: Correlation of hemoglobin concentration with duration of cement dust exposure in study group presenting there is negative correlation between hemoglobin concentraton and duration of cement dust exposure. $\mathrm{Hb}=$ hemoglobin concentration.

\section{Discussion}

In the present study, mean hemoglobin concentration and total count of RBC were lower in subjects exposed to cement dust than that of controls. This result is similar to others ${ }^{2,14}$. Negative correlation was observed between the hemoglobin concentration and duration of cement dust exposure. Similar findings were observed in other studies ${ }^{14,15}$. Literature review suggested that chronic exposure to toxic components of cement dust (crystalline silica, hexavalent chromium, calcium oxide, aluminium) induce inflammation with accumulation of neutrophils, macrophage and lymphocytes in the lung. Very small particles like cement dust (diameter range of 0.05ì and 5.0 ì) can also pass into circulation $2,16,17$.

Phagocytosis of silica by alveolar macrophage gives rise to increased oxygen consumption, production of superoxide anion $\left(\mathrm{O}_{2} \bullet\right), \mathrm{H}_{2} \mathrm{O}_{2}$, and increased $\mathrm{NO} \bullet$ synthesis. Free radical damage to cells result in cascade of cellular responses such as pro-inflammatory cytokine like tumor necrosis factor-á (TNF-á), interleukins (IL-1,IL-8) release and activation of transcription factor such as nuclear factor ê-B and activator protein-1 ${ }^{6,18}$. Both NF-êâ and TNFá inhibit globin genes expression. This may result in decreased globin formation and hemoglobin production ${ }^{19}$.

Crystalline silica found in cement dust has a silanol group on its surface. This silanol group can form hydrogen bond with the nitrogen and oxygen group of biological membranes and may produce $\mathrm{H}_{2} \mathrm{O}_{2}$ in large quantity. This $\mathrm{H}_{2} \mathrm{O}_{2}$ causes $\mathrm{Hb}$ denaturation and leads to cell membrane rupture. $\mathrm{H}_{2} \mathrm{O}_{2}$ reacts with metal ions such as iron $\left(\mathrm{Fe}^{2+}\right)$ present in hemoglobin to form hydroxyl radical by Fenton reaction. The reaction results in conversion of oxyhemoglobin having $\mathrm{Fe}^{2+}$ to methhemoglobin having $\mathrm{Fe}^{3+}$ in red blood cells and hydoxyl ion causes lipid peroxidation of red blood cell membrane ${ }^{6,20}$.

Transcription factor GATA-1 is essential for survival of erythroid progenitors as well as the terminal differentiation of erythroid cells. TNFá, produced by alveolar macrophage upon cement dust exposure, causes inhibition of GATA-1. Down regulation of GATA-1 inhibits erythropoiesis. This may result in decrease in red blood cells ${ }^{17}$.

\section{Conclusion}

After analyzing the results of the study, it can be concluded that exposure to cement dust has deleterious effect on the hemoglobin concentration and total count of RBC. Moreover the duration of cement dust exposure has an impact on the hemoglobin concentration

Conflict of Interest None

Acknowledgement

The authors acknowledged the Department of Laboratory Medicine, Dhaka Medical College hospital, Dhaka for their kind cooperation to carry out the laboratory investigations. 


\section{References}

1. Calvert JG .Glossary of atmospheric chemistry terms (Recommendations 1990), Pure Appl Chem.1990; 62(11): 2167-219.

2. Al Salhen KSA. Assessment Of oxidative stress, Haematological, kidney and liver function parameters of Libyan cement factory workers. J Am Sci 2014;10(5):58-65.

3. Gbadebo AM, Bankole OD.Analysis of potentially toxic metals in airborne cement dust around Sagamu, Southwestern Nigeria. J Appl Sci 2007; 7:35-40.

4. Abdelhamid A . Effect of exposure to Portland cement dust on the periodontal status and on the outcome of non-surgical periodontal therapy. Int $\mathbf{J}$ Health Sci 2016; 10 (3): 339-52.

5. Abdelhamid $\mathrm{H}$, Mohammed MN, Alrazig SA, Tajalser T, Suliman E, AbdAllah K, Muzamil N, Ahmed SE, Albakry MM, Altaib Z .Assessment of allergy marker leucocyte (Eosinophil) count and other blood cells parameters among workers at Berber cement factory, Berber governorate, river Nile state, Sudan, 2017. Global J Med Res :(C )Microbiol Pathol 2017;17: 1-3.

6. Castranova V. Signalling pathways controlling the production of inflammatory mediators in response to crystalline silica exposure: role of reactive oxygen/nitrogen species. Free Radic Biol Med 2004; 37(7):916-25.

7. Gulumian M, Born PJA, Vallyathan V, Castranova V, Donaldson K, Nelson G, Murray J . Mechanistically identified suitable biomarkers of exposure, effect, and susceptibility for silicosis and coal worker's pneumoconiosis: A comprehensive review. J Toxicol Environ Health part B 2006; 9(5): 357-95.

8. Rampuri S. Study and analysis of occupational \& health diseases in cement industries. Int J Adv Res Dev 2017; 2(3):1-7.

9. Eastern Bank Limited Securities Limited. Cement industries of Bangladesh. Dhaka: EBLSL 2017 p. $1-2$.

10. Jasim, RH .2012 Evaluation of some trace element levels in sera samples of Kufa cement factory workers. J Photocat Sci (JPS) 2012; $3:$ 9-15.
11. World Health Organization. Global health risks . Geneva: WHO 2009; p. 25.

12. World Health Organization. Haemoglobin concentrations for the diagnosis of anaemia and assessment of severity. Vitamin and Mineral Nutrition Information System. Geneva: WHO 2011; p.1-6

13. Vlagopoulos PT, Tighiouart H, Weiner DE, Griffith J, Pettitt D, Salem DN, Levey AS, Sarnak MJ . Anemia as a risk factor for cardiovascular disease and all-cause mortality in diabetes: The impact of chronic kidney disease. J Am Soc Nephrol 2005; $16: 3403-10$.

14. Emmanuel TF, Ibiam UA, Okaka ANC, Alabi OJ 2015. Effects of cement dust on the hematological parameters in Obajana cement factory workers. Euro Sci J 2015; 11(27) : 256-66.

15. Jude ALC, Sasikala K, Kumar RA, Sudha S and Raichel J . 2002, Haematological and cytogenetic studies in workers occupationally exposed to cement dust. Int J Hum Genet 2002; 2 (2) : 95-9.

16. Freitus Jr, RA, Nanomedicine, vol. II A, Biocompatibility [Internet]. Landes Biosci. [updated 2004 Apr 30; cited 2018 Sep 11]. Available from http://www.nanomedicine.com/NMIIA/ 15.4.3.3.2.html

17. Thomas, RJ . Particle size and pathogenicity in the respiratory tract. Virulence.2013; 4(8): 847-58.

18. Hamilton Jr RF, Thakur SA, Holian A. Silica binding and toxicity in alveolar macrophages [Internet]. Free Radic Biol Med. [updated 2008 Apr 1; cited 2018 May 8]. Available from: https:/ /www.ncbi.nlm.nih.gov/pmc/articles/PMC2680955/

19. Morceau F, Dicato M, Diederich. Proinflammatory cytokine-mediated anemia: regarding molecular mechanisms of erythropoiesis [Internet]. Mediat Inflamm. [updated 2010 Mar 1; cited 2018 Aug 9]. Available from: http://www.hindawi.com/ journals/mi/2009/405016/

20. Razzaboni BL and Bolsaitis P. Evidence of an oxidative mechanism for the hemolytic activity of silica particles . Environ Health Perspect 1990; 87 :337-41. 